\title{
PEMBERDAYAAN PEREMPUAN MELALUI PEMANFAATAN DAN PENATAAN PEKARANGAN
}

\author{
Achmad Faqih \\ Program Studi Agribisnis Fakultas Pertanian Universitas Swadaya Gunung Jati Cirebon \\ Jalan Pemuda No.32 Cirebon - Jawa Barat - Indonesia \\ E-mail: achmadfaqih2311@gmail.com \\ (Diterima 18-02-2020; Disetujui 22-03-2020)
}

\begin{abstract}
ABSTRAK
Desa Sirnabaya memiliki potensi sumberdaya alam yang melimpah, namun realisasi konsumsi masyarakat masih di bawah anjuran pemenuhan gizi. Oleh karena itu, salah satu upaya untuk meningkatkan ketahanan pangan keluarga dan gizi masyarakat harus diawali dari pemanfaatan sumberdaya yang tersedia maupun yang dapat disediakan di lingkungannya. Upaya tersebut ialah memanfaatkan pekarangan yang dikelola oleh keluarga. Kegiatan Kawasan Rumah Pangan Lestari (KRPL) diharapkan dapat mengoptimalkan pemanfaatan lahan pekarangan. Kegiatan pengabdian masyarakat ini dilakukan pada Kelompok Wanita Tani Desa Sirnabaya, Kecamatan Gunung Jati, Kabupaten Cirebon dari bulan April sampai bulan Agustus 2019. Pengabdian masyarakat ini bertujuan untuk: (1) Meningkatnya kesadaran masyarakat terutama perempuan melalui pemanfaatan dan penataan pekarangan, dan (2) Meningkatnya keterlibatan dan kemampuan masyarakat lokal untuk berpartisipasi secara aktif dan diberdayakan dalam upaya pemberdayaan pemanfaatan dan penataan pekarangan. Metode yang digunakan dalam pengabdian masyarakat ini adalah: (1) Penentuan prioritas program bersama sasaran program/kelompok wanita tani, (2) Penyuluhan dan pelatihan pengelolaan dan pentaan pekarangan, (3) Pelaksanaan kegiatan pemanfaatan dan pentaan pekarangan, dan (3) Monitoring dan evaluasi terhadap pelaksanaan kegiatan program yang dilakukan. Hasil pengabdian masyarakat menunjukkan bahwa: (1) Pendampingan yang dilakukan dalam program pemberdayaan perempuan di Desa Sirnabaya dilakukan secara menyeluruh, (2) Dampak program KRPL terhadap tingkat pendapatan rumah tangga di Desa Sirnabaya rata-rata memberikan konstribusi 53 persen, (3) Dampak program KRPL terhadap pola pengeluaran dan konsumsi pangan adalah berkembangnya kemampuan keluarga dan masyarakat secara ekonomi dan sosial dalam memenuhi kebutuhan pangan dan gizi secara lestari, dan (4) Evaluasi dilakukan kepada pelaksanaan program pemberdayaan perempuan melalui pemanfatan dan penataan pekarangan itu sendiri.
\end{abstract}

Kata Kunci: Pemberdayaan, Perempuan, Pemanfatan, Penataan Pekarangan

\section{PENDAHULUAN}

Secara nasional, luas lahan pekarangan adalah sekitar 10,3 juta ha atau 14 persen dari keseluruhan luas lahan pertanian (Badan Litbang Pertanian, 2011). Kementerian Pertanian memanfaatkan potensi tersebut untuk mewujudkan kemandirian pangan serta meningkatkan kesejahteraan keluarga, baik untuk rumah tangga pedesaan maupun perkotaan melalui pengembangan Model Kawasan Rumah Pangan Lestari (M-KRPL) dan replikasinya menjadi Kawasan Rumah Pangan Lestari (KRPL). Prinsip dari M-KRPL sebagaimana tercantum dalam Perdum 2011 yaitu dibangun dari perkumpulan rumah tangga yang mampu mewujudkan kemandirian pangan melalui pemanfaatan pekarangan, dapat melakukan upaya diversifikasi pangan berbasis sumberdaya lokal dan sekaligus pelestarian tanaman pangan untuk masa depan, serta peningkatan kesejahteraan rumah tangga (Saputro, 2001).

Kata "Kawasan" dan "Lestari" menjadi dua kunci dari program M-KRPL/KRPL. Konsep kawasan dirancang untuk pengembangan M-KRPL/KRPL dalam suatu kawasan yang 
relative terkonsentrasi sehingga memudahkan dalam pengelolaan, pendampingan, serta memberikan nilai ekonomi bagi masyarakat karena menghasilkan produk pangan yang dapat dipasarkan. Sementara itu, konsep lestari dirancang dengan pengembangan Kebun Bibit Desa (KBD) dan Kebun Bibit Induk (KBI) dimasing-masing BPTP agar program ini dapat berkelanjutan (Badan Litbang Pertanian, 2011).

Kementerian Pertanian melalui Badan Litbang Pertanian mengembangkan suatu Model Kawasan Rumah Pangan Lestari (M-KRPL) dan replikasinya yang disebut KRPL untuk optimalisasi pemanfaatan lahan pekarangan, utamanya melalui pemanfaatan berbagai inovasi yang telah dihasilkan oleh badan litbang pertanian. Program M-KRPL/KRPL telah diangkat menjadi program nasional, pada tahun 2011 setiap BPTP mengembangkan 1-2 lokasi, dan pada tahun 2012 ini rata-rata replikasi dilakukan untuk 4 lokasi pada masing-masing provinsi. Sementara itu, beberapa provinsi telah menganggarkan pengembangan KRPL 2-3 kelompok/desa per kabupaten dengan mengacu percontohan M-KRPL yang diinisiasi oleh BPTP. Mengingat bahwa konsep M-KRPL dan KRPL hanya didasarkan pada satu uji coba yang sangat kecil skalanya, maka upaya untuk terus melakukan evaluasi demi perbaikan konsep dan implementasi M-KRPL dan KRPL secara terus menerus harus dilakukan agar program ini dapat memberikan hasil seperti yang diharapkan (Sawit, 2012).

Faktor utama perwujudan program KRPL adalah bahwa ketahanan pangan nasional dimulai dari bawah, yaitu dimana rumah tangga merupakan objek dasar acuan terbentuknya konsep ketahanan pangan. Bila satu rumah tangga dapat mengantisipasi pemenuhan kebutuhan pangan secara mandiri dan dapat mengkonsumsi pangan yang beragam, maka prinsip perubahan pola konsumsi masyarakat Indonesia dapat mengindikasikan terbentuknya ketahanan pangan yang berkembang secara signifikan, mandiri dan dapat mengurangi kuota impor akan beras (Danoesastro, 1998).

Salah satu fungsi pengembangan ketahanan pangan itu sendiri, selain dari segi ekonomi rumah tangga, adalah fungsi adanya upaya dalam kontek pemenuhan kebutuhan gizi masyarakat, khususnya kalangan menengah ke bawah. Dengan adanya pola konsumsi beragam dan tidak hanya mengutamakan beras sebagai makanan wajib diharapkan gizi yang diberlakukan sehingga sumberdaya manusia terbentuk ideal.

Gizi yang seimbang tidak hanya dilihat dari jumlah atau kuantitas pangan yang dikonsumsi, namun juga perlu dilihat dari segi keragaman pangan yang dikonsumsi. Pangan beragam yang dikonsumsi akan mencerminkan keragaman zat gizi ideal yang dapat dianalisis dari pola pangan harapan yang menjadi acuan untuk menilai tingkat keragaman konsumsi pangan dengan skor 100 sebagai pola yang ideal. 
Luas lahan pekarangan secara nasional sekitar 10,3 juta ha atau 14 persen dari keseluruhan luas lahan pertanian. Lahan pekarangan merupakan salah satu sumber potensi penyedia bahan pangan yang bernilai gizi, mengurangi pengeluaran rumah tangga, dan menambah sumber pendapatan. Lahan pekarangan mempunyai multi fungsi meliputi pelestarian sumberdaya alam dan lingkungan, pelindung sumberdaya plasma nutfah atau biodiversitas, fungsi ekonomi, fungsi sosial, dan sebagian besar lahan pekarangan tersebut masih belum dimanfaatkan sebagai areal pertanaman aneka komoditas pertanian, baik untuk komoditas padi-padian, umbi-umbian, sayuran, buah-buahan, tanaman biofarmaka, serta ternak dan ikan (Hanafi, 1991).

Desa Sirnabaya memiliki potensi sumberdaya alam yang melimpah. Kesediaan jenis pangan dan rempah yang beraneka ragam, berbagai jenis tanaman pangan seperti, padipadian, umbi-umbian, kacang-kacangan, sayuran, buah-buahan dan pangan dari hewani banyak kita jumpai. Namun demikian, realisasi konsumsi masyarakat masih di bawah anjuran pemenuhan gizi. Oleh karena itu, salah satu upaya untuk meningkatkan ketahanan pangan keluarga dan gizi masyarakat harus diawali dari pemanfaatan sumberdaya yang tersedia maupun yang dapat disediakan di lingkungannya. Upaya tersebut ialah memanfaatkan pekarangan yang dikelola oleh keluarga. Kegiatan Kawasan Rumah Pangan Lestari (KRPL) diharapkan akan mengoptimalkan pemanfaatan lahan pekarangan.

Lahan pekarangan dapat dimanfaatkan untuk berbagai tujuan, misalnya sebagai warung hidup dan apotik hidup, dan memberikan keindahan lingkungan tempat tinggal. Penataan bentuk dan pola pekarangan berbeda-beda. Lahan pekarangan dapat dijadikan aset berharga bagi pengembangan usaha tani untuk menambah pendapatan rumah tangga. Oleh karena itu, pemanfaatan lahan pekarangan dapat dijadikan basis usaha pertanian dalam rangka memberdayakan sumberdaya keluarga serta meningkatkan ketahanan pangan dan kecukupan gizi. Dalam rangka mencapai ketermanfaatan pekarangan rumah tangga, ada beberapa kegiatan utama yang harus dilakukan di antaranya pembuatan Kebun Bibit Desa (KBD) serta pengenalan pendampingan penerapan teknologi budidaya tanaman sayuran.

Lokasi Kebun Bibit Desa harus strategis guna memudahkan distribusi bibit serta diseminasi pada masyarakat. Di dekat lokasi saung dibuat percontohan penanaman sayuran model bedengan dengan mulsa. Selain itu, ada beberapa tanaman induk untuk memproduksi bibit tanaman. Pada proses pembuatan KBD, KWT Mutiara Putih berperan aktif melakukan penanaman serta pemeliharaan bibit sayuran sebelum didistribusikan pada masyarakat.

KBD ini selain digunakan untuk tempat pembibitan sayuran, juga menjadi sentra pertemuan dan pelatihan budidaya sayuran beserta media tanam. Komoditas utama yang 
dikembangkan adalah kangkung, salam, jagung, jeruk nipis, jeruk limau, timun suri, dan tanaman merambat seperti paria, kacang panjang, dan oyong. Masyarakat mengambil bibit sayuran dari KBD untuk ditanam di pekarangan mereka. Masyarakat menggunakan ember bekas yang dilubangi bagian bawah untuk media tanam.

KRPL Desa Sirnabaya diharapkan dapat terwujud nyata dalam membantu pemenuhan gizi rumah tangga dengan mengkonsumsi pangan lokal dari pekarangan sendiri, sehingga menurunkan angka ketergantungan terhadap beras dan meningkatkan partisipasi pangan untuk komoditas non beras lainnya yang didapat secara mandiri melalui program KRPL tersebut. Oleh karena itu, peneliti melakukan observasi dari aspek pola konsumsi dan gizi di salah satu KRPL Desa Sirnabaya.

Pendekataan pemberdayaan masyarakat yang berpusat pada manusia (people centered development) melandasi wawasan pengelolaan sumberdaya lokal, yang merupakan mekanisme perencanaan yang menekankan pada teknologi pembelajaran sosial dan strategi perumusan program (Mardikanto, 2010) dalam Faqih (2016) dan Korten (1987). Tujuan yang ingin dicapai adalah untuk meningkatkan kemampuan masyarakat dalam mengaktualisasikan dirinya (Erwin, 2011).

Mengingat hal tersebut di atas, maka penulis tertarik untuk mengadakan pengabdian masyarakat mengenai pemberdayaan perempuan melalui pemanfaatan dan penataan pekarangan (Rooganda. 2007).

\section{Identifikasi Masalah}

Berdasarkan uraian latar belakang, maka sebagai pembahasan yang lebih rinci lagi dalam masalah tersebut penulis mengidentifikasi sebagai berikut:

1. Masih lemahnya kesadaran masyarakat terhadap pemanfaatan dan penataan pekarangan.

2. Masih kurangnya keterlibatan dan kemampuan masyarakat lokal untuk berpartisipasi secara aktif dan diberdayakan dalam upaya berbagai pelestarian lingkungan serta dalam proses pengambilan keputusan untuk pengelolaan sumberdaya alam.

3. Belum dilaksanakannya secara optimal dan berkelanjutan kegiatan pemanfaatan dan pengelolaan sumberdaya alam memalui pemanfaatan dan penataan pekarangan.

\section{Tujuan Kegiatan}

Tujuan dari kegiatan program ini adalah:

1. Meningkatnya kesadaran masyarakat terutama perempuan melalui pemanfaatan dan penataan pekarangan. 
2. Meningkatnya keterlibatan dan kemampuan masyarakat lokal untuk berpartisipasi secara aktif dan diberdayakan dalam upaya pemberdayaan pemanfaatan dan penataan pekarangan.

3. Dilaksanakannya secara optimal dan berkelanjutan kegiatan pengelolaan sumberdaya alam melalui pemanfaatan dan penataan pekarangan.

\section{Manfaat Kegiatan}

Manfaat dari kegiatan program ini adalah:

1. Menyebarnya teknologi pengelolaan pemanfaatan dan penataan pekarangan.

2. Tumbuhnya kesadaran masyarakat terhadap pemanfaatan dan penataan pekarangan.

\section{Khalayak Sasaran}

Desa Sirnabaya Kecamatan Gunung Jati Kabupaten Cirebon merupakan salah satu daerah dengan lahan pekarangan yang cukup luas. Berdasarkan hasil survey pendahuluan di lapangan terdapat warga masyarakat yang kehidupannya belum bisa memanfaatkan dan mengelola sumberdaya alam berupa penataan pekarangan karena sarana produksi, pengetahuan dan keterampilan, serta faktor eksternal seperti keterbatasan pelayanan dan penyediaan fasilitas oleh pemerintah.

\section{BAHAN DAN METODE}

\section{Metode Pengabdian}

Metode pengabdian masyarakat yang dilakukan untuk mencapai tujuan adalah dijabarkan melalui kegiatan-kegiatan sebagai berikut: (1) Penentuan prioritas program bersama sasaran program, (2) Penyuluhan dan pelatihan pengelolaan dan pentaan pekarangan, (3) Pelaksanaan kegiatan pemanfaatan dan pentaan pekarangan, dan (4) Monitoring dan Evaluasi terhadap pelaksanaan kegiatan program yang dilakukan.

\section{Target Luaran}

1) Meningkatkan pengetahuan masyarakat dalam pemanfaatan dan pentaan pekarangan, 2) Meningkatkan kesadaran masyarakat dalam kegiatan pemanfaatan dan pentaan pekarangan, dan 3) Meningkatan peran lembaga sosial dan ekonomi dalam pemanfaatan dan pentaan pekarangan. 


\section{Monitoring dan Evaluasi}

Monitoring dan evaluasi dilaksanakan mulai bulan kedua setelah pelaksanaan sampai dengan bulan ke lima menjelang selesainya kegiatan. Adapun kriteria, indikator pencapaian tujaun dan tolak ukur yang digunakan untuk menyatakan keberhasilan kegiatan dapat dilihat pada Tabel 1.

Tabel 1. Kriteria, Indikator dan Tolak Ukur Keberhasilan Program Pemberdayaan/Pengabdian Masyarakat

\begin{tabular}{|c|c|c|}
\hline Kriteria & Indikator & Tolok Ukur \\
\hline $\begin{array}{l}\text { Jumlah peserta yang tertarik untuk } \\
\text { hadir dalam kegiatan pemberdayaan }\end{array}$ & $\begin{array}{l}\text { Frekuensi kehadiran tiap peserta dalam } \\
\text { kegiatan pemberdayaan }\end{array}$ & Absensi/ Daftar hadir \\
\hline $\begin{array}{l}\text { Tingkat } \begin{array}{r}\text { kemudahan } \\
\text { penyelenggraan program dalam } \\
\text { kegiatan pemberdayaan }\end{array} \\
\end{array}$ & $\begin{array}{l}\text { Jumlah dan jenis ide yang dikemukakan } \\
\text { oleh perta dalam kegiatan pemberdayaan }\end{array}$ & Banyaknya ide/gagasan \\
\hline $\begin{array}{l}\text { Tingkat penerapan kegiatan } \\
\text { program oleh peserta }\end{array}$ & $\begin{array}{l}\text { Jumlah peserta yang mampu menerapkan } \\
\text { hasil kegiatan program }\end{array}$ & $\begin{array}{l}\text { Peserta yang mampu } \\
\text { menerapkan }\end{array}$ \\
\hline $\begin{array}{l}\text { Meningkatnya jumlah masyarakat } \\
\text { dalam kegiatan pemanfaatan dan } \\
\text { pentaan pekarangan }\end{array}$ & $\begin{array}{l}\text { Bertambahnya masyarakat yang terlibat } \\
\text { dalam kegiatan pemanfaatan dan pentaan } \\
\text { pekarangan }\end{array}$ & $\begin{array}{l}\text { Peserta yang mampu } \\
\text { menerapkan pemanfaatan } \\
\text { dan pentaan pekarangan }\end{array}$ \\
\hline
\end{tabular}

Sumber: Soetomo, 2008

\section{Jadwal Pelaksanaan Kegiatan}

Kegiatan pengabdian masyarakat lahan/pekarangan pantai utara jawa (Pantura) di Desa Sirnabaya Kecamatan Gunung Jati Kabupaten Cirebon ini dilaksanakan selama 5 bulan. Adapun rencana kegiatan dapat dilihat pada Tabel 2.

Tabel 2. Jadwal Kegiatan pengabdian masyarakat pemanfaatan dan pentaan pekarangan

\begin{tabular}{|c|c|c|}
\hline No & Kegiatan & Waktu \\
\hline 1 & Survey lapangan & 01-04-2019 s/d 30-04-2019 \\
\hline 2 & Pengurusan perijinan & 01-05-2019 s/d 07-05-2019 \\
\hline 3 & Persiapan bahan dan alat & 08-05-2019 s/d 30-05-2019 \\
\hline 4 & Penyiapan materi pelatihan & 01-06-2019 s/d 07-06-2019 \\
\hline 5 & Penyuluhan dan pelatihan pemanfaatan dan pentaan pekarangan & 17- 06-2019 \\
\hline 6 & Penyuluhan kesadaran masyarakat pemanfaatan dan pentaan pekarangan & 30-06-2019 \\
\hline 7 & Monitoring dan Evaluasi kegiatan pemberdayaan masyarakat & 01-07-2019 s/d 30-07-2019 \\
\hline 8 & Pembuatan laporan kegiatan & 01-08-2019 s/d 15-08-2019 \\
\hline
\end{tabular}

\section{HASIL DAN PEMBAHASAN}

Bentuk pelaksanaan kegiatan pengabdian pada masyarakat adalah melaui pemberdayaan masyarakat/penyuluhan dengan cara pendampingan, pelatihan dan peningkatan akses modal dalam pemanfaatan dan pengelolaan sumberdaya lahan/pekarangan. Program Pemberdayaan Perempuan melalui pemanfatan dan penataan pekarangan merupakan upaya untuk menjawab permasalahan masyarakat lahan/pekarangan di Desa Sirnabaya Kecamatan Gunung Jati Kabupaten Cirebon. Melalui program tersebut masyarakat yang mempunyai lahan lahan/pekarangan dengan wadah kelompok wanita tani mempunyai kebebasan untuk memilih, merencanakan dan menetapkan kegiatan ekonomi yang dibutuhkan berdasarkan musyawarah. 
Dengan demikian, masyarakat merasa memiliki dan bertanggung jawab atas pelaksanaan, pengawasan dan berkelanjutan.

\section{1) Pendampingan Program Pemberdayaan Perempuan melalui pemanfatan dan penataan pekarangan}

Arti dari pendampingan itu sendiri adalah menemani atau menyertai sesuatu atau program tertentu, lebih tepatnya membimbing untuk mencapai tujuan yang telah ditetapkan. Pendampingan yang dilakukan dalam program pemberdayaan perempuan di Desa Sirnabaya dilakukan secara menyeluruh dalam kegiatan kelompok wanita tani melalui pemanfatan dan penataan pekarangan, yang terlibat langsung dengan kegiatan pendampingan program ini masyarakat dalam merumuskan program kegiatan yang akan dilakukan.

Pendampingan dilakukan dilakukan secara bertahap dan seyogyanya dilaksanakan dengan pendekatan partisipatif. Artinya, segala keputusan ada di tangan masyarakat untuk menentukan aktivitas apa yang akan menjadi pilihan dalam memperbaiki kesejahteraannya, atau melanjutkan aktivitas ekonomi tersebut bagi masyarakat dengan teknologi yang lebih baik.

Kehadiran pendamping sangatlah dibutuhkan untuk membimbing masyarakat baik di bidang ekonomi maupun pendidikan (Faqih, 2017). Walaupun kelompok wanita tani telah diberikan pelatihan, namun tetap saja masyarakat membutuhkan pendamping yang lebih mampu mengerti keinginan mereka karena telah beradaptasi dengan kehidupan sosial mereka. Sifat dasar masyarakat adalah tidak mudah menerima orang baru dalam kehidupan masyakaratnya, namun jika telah mengenal lebih jauh tentang mereka, maka rasa kekeluargaannya lebih erat sama seperti saudara.

\section{2) Pelatihan Program Pemberdayaan Perempuan melalui pemanfatan dan penataan pekarangan}

Pelatihan merupakan tindak lanjut dari pelaksanaan program pemberdayaan perempuan ini, yang diikuti oleh KWT. Tujuannya berbeda-beda sesuai dengan fungsi dari lembaga itu sendiri. Untuk KWT, pelatihan ini bertujuan memberi pengetahuan dan keterampilan dalam mengelola aktivitas ekonominya, baik yang berupa pemanfatan lahan atau pekarangan. Sehingga pada saat pelaksanaan, kelompok ini telah siap untuk menerapkan dalam mengelola pekarangannya. Selain itu, untuk mempersiapkan kader-kader dari wanita tani itu sendiri agar dapat memberi atau membagi informasi pengetahuan kepada anggota masyarakat lainnya bahwa program ini adalah cara atau jalan keluar dari permasalahan yang dihadapi. 
Pelatihan pemanfatan lahan dan penataan pekarangan dimaksudkan untuk memberi pengetahuan bagaimana teknik memberdayakan lahan/pekarangan yang tergolong rendah dalam pemanfatan lahan, bagaimana menjadi pendamping yang baik dan bagaimana cara mengatasi permasalahan yang ditemui di lapangan. Bagi KWT, pelatihan ini bertujuan untuk mengetahui manajemen pengelolaan organisasi dengan baik dan benar dan selalu berjalan bersama dengan kepentingan anggota kelompoknya.

Pelatihan yang dilakukan pada KWT sesuai dengan rencana yang telah ditetapkan. Output dari pelatihan ini adalah kemampuan dalam mengembangkan teknik pemanfatan lahan/pekarangan yang mempunyai spesifikasi yang berbeda-beda untuk setiap lokasinya. Untuk KWT sendiri, hasil yang diperoleh adalah pengetahuan mengelola manajemen dalam kelompok itu sendiri dan bisa mengetahui perkembangan program pemberdayaan perempuan. Kenyataan di lapangan, ada beberapa individu dari kelompok ini yang tidak menerapkan atau tidak membagi pengetahuan dengan masyarakat lainnya.

\section{3) Dampak Program KRPL Terhadap Tingkat Pendapatan Rumah Tangga}

Hasil produksi pekarangan adalah untuk konsumsi rumah tangga pada rumah tangga peserta Program Model Kawasan Rumah Pangan Lestari (M-KRPL) di Desa Sirnabaya hasil pekarangan rata-rata memberikan konstribusi 53 persen. Pada rumah tangga peserta hasil pekarangan yang dijual dan ditransfer memberikan konstribusi relatif sama (22\%). Hal ini sangat mendukung salah satu tujuan program M-KRPL untuk meningkatkan ketahanan pangan rumah tangga dan kawasan atau wilayah.

Sebagian usahatani tanaman di lahan perkarangan masih diusahakan secara tradisional hingga semi intensif. Seluruh komoditas yang ditanam (tanaman introduksi maupun tanaman yang telah ada) di lahan perkarangan adalah menguntungkan. Hampir semua usahatani yang dilakukan memberikan keuntungan positif, dari cukup menguntungkan hingga sangat menguntungkan. Rata-rata nilai $\mathrm{R} / \mathrm{C}$ ratio $>1$, artinya bahwa tingkat efektivitas pengembalian modal cukup baik hingga sangat baik.

Kontribusi produksi yang bersumber dari lahan perkarangan terhadap struktur pendapatan rumah tangga yang berbeda antar strata, pada skala 1 konstribusi lahan perkarangan terhadap pendapatan sekitar $3,16 \%$, pada strata 2 kurang lebih $6,81 \%$, dan pada strata 3 kurang lebih 10,3\%. Kontribusi terbesar secara berturut-turut adalah kelompok kelompok komoditas sayuran, umbi-umbian, perternakan, dan buah-buahan. 


\section{4) Dampak Program KRPL Terhadap Pola Pengeluaran dan Konsumsi Pangan}

Kawasan Rumah Pangan Lestari (KRPL) didefinisikan sebagai kawasan dimana setiap unit rumah tangga memanfaatkan pekarangan secara intensif melalui pengolahan sumberdaya alam lokal secara bijaksana, yang menjamin kesinambungan persediaannya dengan tetap memelihara dan meningkatkan kualitas, nilai dan keanekaragamannya. Konsep tersebut lebih mengarah bagaimana mengoptimalkan pemanfaatan pekarangan antara lain untuk lebih berdaya guna, walaupun di beberapa wilayah hal tersebut sudah dilakukan. Sasaran yang ingin dicapai dari program KRPL adalah berkembangnya kemampuan keluarga dan masyarakat secara ekonomi dan sosial dalam memenuhi kebutuhan pangan dan gizi secara lestari. Menuju keluarga dan masyarakat yang sejahtera serta terwujudnya diversifikasi pangan dan pelestarian tanaman pangan lokal.

Diversifikasi pangan berperan penting dalam mewujudkan ketahanan pangan, karena kualitas konsumsi pangan dilihat dari indikator skor Pola Pangan Harapan (PPH) Nasional masih rendah. KRPL adalah salah satu solusi ketahanan pangan berbasis rumah tangga. Kementerian Pertanian melalui Badan Litbang Pertanian dan Balai Pengkajian Teknologi Pertanian telah membuat model penerapan KRPL, diharapkan pada setiap kabupaten harus memiliki satu model KRPL. Di Desa Sirnabaya Kabupaten Cirebon menunjukan bahwa hasil produksi pekarangan adalah untuk konsumsi rumah tangga, pada rumah tangga peserta program M-KRPL di Desa Sirnabaya hasil pekarangan rata-rata memberikan kontribusi 53 persen. Hal ini sangat mendukung salah satu tujuan Program KRPL untuk meningkatkan ketahanan pangan rumah tangga dan kawasan atau wilayah. Khusus di lokasi program dari konsumsi yang bersumber dari pekarangan bila dirinci lebih lanjut secara berturut-turut adalah kelompok komoditas sayuran (50\%), komoditas umbi-umbian (30\%), kelompok komoditas peternakan khususnya telur ayam (20\%), buah-buahan (15\%), dan daging/hasil ternak (10\%).

Kebutuhan rumah tangga dapat dikelompokkan ke dalam dua kategori besar, yaitu kebutuhan akan pangan dan bukan pangan (Faqih, 2015). Dengan demikian, pada tingkat pendapatan tertentu, rumah tangga akan mengalokasikan pendapatannya untuk memenuhi kedua kebutuhan tersebut. Secara alamiah kuantitas pangan yang dibutuhkan seseorang akan mencapai titik jenuh sedangkan kebutuhan bukan pangan relatif tidak terbatasi dengan titik jenuh. Oleh karena itu, besaran pendapatan (diproksi dengan pengeluaran total) yang dibelanjakan untuk pangan dari suatu rumah tangga dapat digunakan sebagai petunjuk tngkat kesejahteraan rumah tangga tersebut. Semakin tinggi pangsa pengeluaran pangan, berarti semakin kurang sejahtera rumah tangga yang bersangkutan. Sebaliknya, semakin kecil pangsa pengeluaran pangan maka rumah tangga tersebut semakin sejahtera. 
Pangsa pengeluaran pangan rumah tangga di Desa Sirnabaya rata-rata lebih dari 60 persen, ini menunjukkan bahwa pengeluaran rumah tangga masih didominasi untuk kelompok pangan, tampak bahwa semakin tinggi pendapatan rumah tangga (proksi pengeluaran total) makin rendah pangsa pengeluaran untuk pangan.

\section{5) Evaluasi Program Pemberdayaan Perempuan Melalui Pemanfatan dan Penataan \\ Pekarangan}

Evaluasi merupakan serangkaian kegiatan yang sistematis yang dilakukan dalam rangka untuk mengetahui apakah suatu kegiatan atau program tertentu telah berjalan sesuai dengan tujuan yang ditetapkan atau belum. Evaluasi dilakukan kepada pelaksanaan program pemberdayaan perempuan melalui pemanfatan dan penataan pekarangan itu sendiri.

\section{KESIMPULAN DAN SARAN}

\section{Kesimpulan}

Berdasarkan hasil pembahasan yang telah dilakukan, ada beberapa hal yang menjadi kesimpulan sebagai berikut:

1. Pendampingan yang dilakukan dalam program pemberdayaan perempuan di Desa Sirnabaya dilakukan secara menyeluruh dalam kegiatan kelompok wanita tani melalui pemanfatan dan penataan pekarangan.

2. Pelatihan pemanfatan lahan dan penataan pekarangan dimaksudkan untuk memberi pengetahuan bagaimana teknik memberdayakan lahan/pekarangan yang tergolong rendah dalam pemanfatan lahan.

3. Dampak program KRPL terhadap tingkat pendapatan rumah tangga di Desa Sirnabaya rata-rata memberikan konstribusi 53 persen.

4. Dampak program KRPL terhadap pola pengeluaran dan konsumsi pangan adalah berkembangnya kemampuan keluarga dan masyarakat secara ekonomi dan sosial dalam memenuhi kebutuhan pangan dan gizi secara lestari. Menuju keluarga dan masyarakat yang sejahtera serta terwujudnya diversifikasi pangan dan pelestarian tanaman pangan lokal.

5. Evaluasi dilakukan kepada pelaksanaan program pemberdayaan perempuan melalui pemanfatan dan penataan pekarangan itu sendiri 


\section{Saran}

1. Untuk memanfaatkan fungsi pekarangan yang ada diperlukan intensifikasi lahan, artinya lahan pertanian yang ada dengan sebaik-baiknya untuk meningkatkan hasil pertanian dengan cara mengoptimalkan lahan pertanian yang sudah ada.

2. Diperlukan pengembangan kebun bibit desa salah satunya mengembangkan bibit tanaman yang bisa dibagikan pada pelaku utama diperlukan peran serta pemerintah dan semua yang terkait dalam upaya pengembangan kebun bibit ini.

3. Untuk meningkatkan hubungan peran dan fungsi kebun bibit desa dengan pemberdayaan perempuan tani perlu dilakukan pemanfaatan kebun bibit yang telah ada, pelaku utama perlu menjadi aktor dalam upaya memaksimalkan pemanfaatan kebun bibit sehingga tujuan utamanya bisa tercapai.

\section{DAFTAR PUSTAKA}

Hanafi, A. 1991. Pemberdayaan Sumberdaya Wanita Melalui Industrialisasi Perdesaan. Departemen Pertanian, Jakarta.

Faqih, A. 2015. Persepsi Anggota Kelompok Tani Terhadap Peranan Kelompok Tani; Logika: Jurnal Ilmiah LEMLIT Unswagati Cirebon, XV(3): 72-89. . 2016. Model Pemberdayaan Kelompok Tani Tanaman Pangan Pesisir Pantai; Ed.1, Cet. 1, Yogyakarta: Penerbit Deepublish.

. 2017. Hubungan Kemampuan Kelompok Dengan Dinamika Kelompok Wanita Tani; Agrijati; Jurnal Ilmiah Ilmu-ilmu Pertanian, 31(1): 27-38.

Badan Litbang Pertanian.2011. Pedoman Umum Model Kawasan Rumah Pangan Lestari. Badan Penelitian dan Pengembangan Pertanian. Jakarta.

Badan Litbang Pertanian. 2012. Pengembangan Kawasan Rumah Pangan Lestari (KRPL). Badan Penelitian dan Pengembangan Pertanian. Jakarta.

Danoesastro, H. 1998. Tanaman Pekarangan dalam Usaha Meningkatkan Ketahanan Rakyat Pedesaan. Agro-ekonomi, 3(1978): 2-25.

Erwin. 2011. Pemberdayaan Perempuan dari Masa ke Masa. Bogor: PT. Penerbit IPB Press. Korten. 1987. Keswadayaan Masyarakat Desa Tertinggal. Yogyakarta: Aditya Media.

Mardikanto, T. 2010. Konsep-Konsep Pemberdayaan Masyarakat. Surakarta: UNS Press.

Roosganda, E. 2007. Pemberdayaan Wanita Mendukung Strategi Gender Mainstreaming Dalam Kebijakan Pembengunan Pertanian di Pedesaan. Pusat Analisis Ekonomi dan Kebijakan Pertanian, Bogor.

Saputro, E.P. (ed). 2001. Pemberdayaan Masyarakat Melalui Ketahanan Pangan Kajian Empiris LSM-LSM Mitra Yayasan Indonesia Sejahtera. Yayasan Indonesia Sejahtera. Jakarta.

Sawit. 2012. Peran Wanita Tani Terhadap Keberhasilan Program Kawasan Rumah Pangan Lestari. Fakultas Pertanian, IPB. Bandung.

Soetomo. 2008. Strategi-Strategi Pembangunan Masyarakat. Yogyakarta: Pustaka Belajar. 